\title{
Pneumologia
}

\section{Epithelioid haemangioendothelioma - A rare cause of pleural effusion}

Ana Constantin, Anca Macri, Florin Dumitru Mihălțan

National Institute of Pneumology Marius Nasta, Bucharest

Abstract

English:

We present the case of a 44-year-old patient, with a history of lymphatic tuberculosis, diagnosed with a pleural effusion associated with pulmonary consolidations. Pleural effusions are frequent in the general population, presenting an incidence of 3-4 cases/1000 people. The etiological diagnosis can be difficult, as they can be secondary to a variety of diseases. Numerous extrapulmonary disorders can explain fluid accumulations in the pleural space with elevated protein level (exudates). However, more frequently they are the result of pulmonary diseases - inflammatory, infectious or neoplastic. The case entailed a differential diagnosis between pulmonary and pleural tuberculosis and neoplastic diseases. Despite receiving antituberculous treatment, the patient's initial symptoms worsen, the patient starts presenting new signs and symptoms, and the fluid's characteristics changeexpression of an unfavourable evolution. Establishing the diagnosis proved to be difficult as invasive procedures were necessary. We diagnosed an extremely rare tumour, of vascular origin as the cause of the pleural effusion. Epithelioid haemangioendothelioma (EHE) presents an incidence of 1 in 1 million people. In conclusion, when treating a patient for pleural effusion, the lack of improvement entails reconsidering the initial diagnosis and performing more extensive tests.

Keywords

\section{Hemangioendoteliomul epitelioid- O cauză rară de pleurezie}

Rezumat

Romanian:

Prezentăm cazul unui pacient în vârstă de 44 de ani, cu istoric de tuberculoză ganglionară, diagnosticat cu pleurezie asociată unor condensări pulmonare. Revărsatele pleurale sunt relativ comune- în populatia generală incidența fiind de 3-4 cazuri/1000 locuitori. Stabilirea diagnosticului etiologic poate fi dificilă, având în vedere că pot fi secundare. Numeroase patologii extrapulmonare pot explica apariția unui revărsat pleural cu conținut ridicat de proteine (exudate). Cu toate acestea mai frecvent sunt determinate de patologii pulmonare- boli inflamatorii, infecțioase sau neoplazice. Cazul a impus diagnosticul diferențial între o neoplazie și tuberculoză pulmonară și pleurală. În ciuda administrării tratamentului antituberculos, la acest pacient se constată agravarea simptomatologiei, apariția unor noi semne și simptome și de asemenea, modificarea caracteristicilor lichdiului pleural, toate aceste elemente traducând o evoluție nefavorabilă. Am diagnosticat o tumoră extrem de rară, de origine vasculară, drept cauză a revărsatului pleural. Incidența hemangioendoteliomului epitelioid este de 1caz/1 milion de locuitori. În concluzie, la un pacient care prezintă revărsat pleural, lipsa unei evoluții favorabile, în ciuda instituirii unei scheme terapeutice, impune reconsiderarea diagnosticului inițial și extinderea plajei de investigații.

Cuvinte-cheie

pleurezie • evoluție dificilă • hemangioendoteliomul epitelioid

\section{Abbreviations}

CT - computed tomography

EHE - epithelioid hemangioendothelioma

${ }^{*}$ Corresponding author: Ana Constantin

E-mail: anactin@gmail.com

\section{Introduction}

Pleural effusions are relatively frequent in the general population; the incidence is $3-4$ cases/1000 people and the aetiology of pleural effusions varies. They can be secondary 
to extrapulmonary pathologies - cardiac, hepatic and renal diseases, but they can also be the consequence of pulmonary disorders - inflammatory, infectious or neoplastic. The differential diagnosis often involves a wide range of tests and can prove to be difficult.

Fifteen per cent of the patients diagnosed with a neoplastic disease present an associated pleural effusion (1). The large majority of pleural effusions are present in lung cancers $(36 \%)$, breast cancers $(25 \%)$, lymphatic cancers $(10 \%)$, ovarian cancers $(5 \%)$ and gastric ones (2\%) (2). In some cases, for example, mesotheliomas, pleural effusions can be present from the early stages, but often they indicate an advanced stage of the disease (1).

The epithelioid haemangioendothelioma (EHE) is an extremely rare malignancy, with an incidence of 1 per 1 million people (3). The origin of the tumour resides in the endothelium (4). It can affect both the young and the elderly (5), both males and females. The disease involves a variety of sites. Frequently it affects the liver $(21 \%)$, both the liver and the lung $(18 \%)$, and the lung alone (12\%) (6). EHE can also involve the head and neck (7), the breasts (7), the lymph nodes (8), mediastinum (9), brain and meninges (10), ovaries (11), prostate (12) and eyelids (13).

At presentation, the patients present symptoms that indicate the extension and localisation of the disease $(14,15)$, general symptoms - fever (1), weight loss (16), but they can also be asymptomatic (17). In cases with pleural involvement, patients usually reported symptoms such as chest pain, dyspnea and productive cough (3).

When diagnosing and monitoring EHE affecting lungs and pleura chest, computed tomography (CT) scans are mandatory. CT scans can reveal diffuse pulmonary nodules, reticulonodular opacities, diffuse pleural thickening, pleural nodules and pleural effusions $(5,18,19)$.

The definitive diagnosis implies a histopathological examination and immunohistochemical tests. Recent research proved that WWTR1-CAMATA1, a fusion protein, can be considered pathognomonic for $\operatorname{EHE}(20,21)$.

The limited number of cases and the polymorphous nature of the disease impede the standardisation of treatment regimens. Patients with a limited-extent of the disease are candidates for curative surgical procedures, while patients with aggressive forms require conservative treatment. Classic chemotherapeutical agents, immunomodulators, tyrosinekinase inhibitors and sirolimus proved useful.

\section{Case Study}

The paper presents the case of a patient aged 44 years, a non-smoker, without any known exposure to toxins, who was admitted to our ward in October 2020 for loss of breath

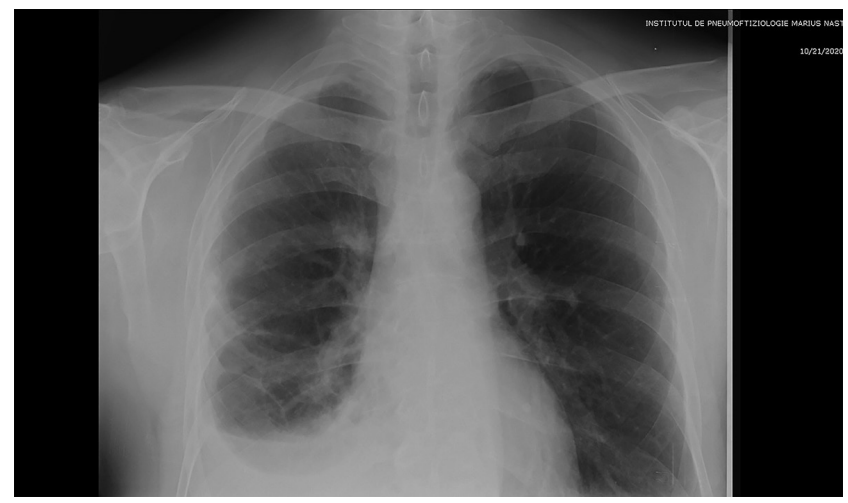

Figure 1. Chest X-ray upon admission- October 2020- Right pleural effusion.

upon moderate exertion, dry cough, and fatigue, symptoms that began 3 weeks before hospital presentation. The patient has a history of lymphatic tuberculosis (2000), for which he received appropriate treatment. The chest x-ray upon admission revealed the presence of a right pleural effusion (Figure 1).

We performed a clinical examination and ascertained absent vesicular murmur and dullness to percussion in the inferior $2 / 3$ of the right chest cavity, without any other pathological elements. We conducted tests on several blood samples. The only abnormal results were lymphopenia and D-dimers with values above normal thresholds $-391 \mu \mathrm{g} / \mathrm{mL}$. The patient undertook a complex functional pulmonary test, that included plethysmography and a carbon monoxide lung diffusion test, which confirmed a restrictive lung disorder consistent with the pleural effusion.

We next performed a therapeutic and diagnostic thoracocentesis, drained $800 \mathrm{~mL}$ of clear citrin pleural fluid, and harvested pleural fragments. We sent samples for biochemical, cytological and microbiological analysis. The examination concluded that the pleural fluid was and exudate, with protein values above normal $(5.3 \mathrm{~g} / \mathrm{dL})$ and did not present any other pathological features. The histopathological examination of the pleural fragments proved to be nondiagnostic. The report described collagenised acellular pleural tissue adjacent to connective tissue and nervous filaments.

The thoracic CT scan noted a right pleural effusion, a consolidation situated in the right lower lobe, diffuse pulmonary nodules, pulmonary consolidations in the right inferior and the middle lobes and bronchiectasis (Figures 2, 3, 4). These radiological aspects entailed a differential diagnosis between a neoplastic disease and an infectious one.

The patient underwent a bronchoscopy. The macroscopic examination showed characteristic of bilateral bronchiectasis, 


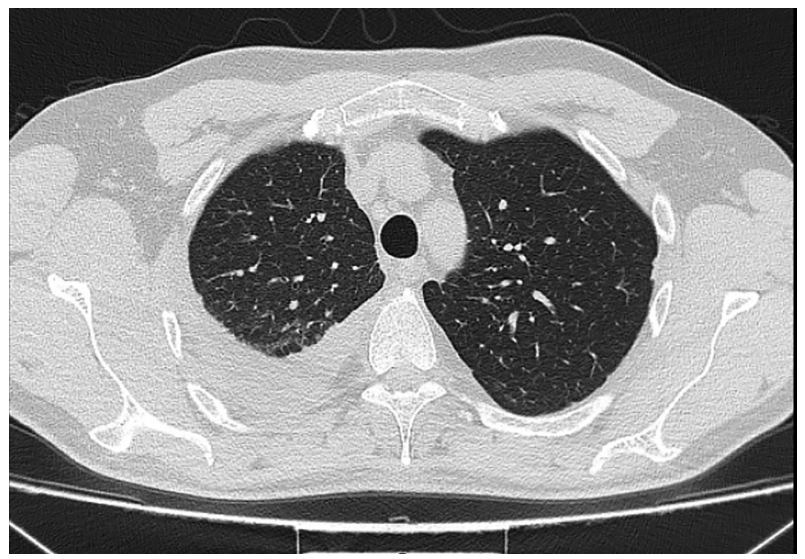

Figure 2. CT scans- October 2020: Right pleural effusion; pulmonary nodules in the upper lobes.

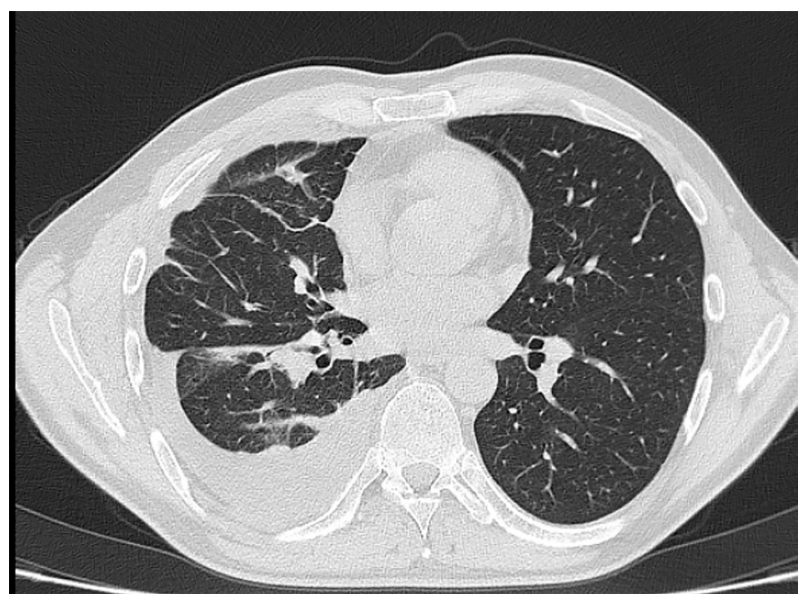

Figure 3. CT scans- October 2020: Right pleural effusion; pulmonary consolidations in the middle lobes.

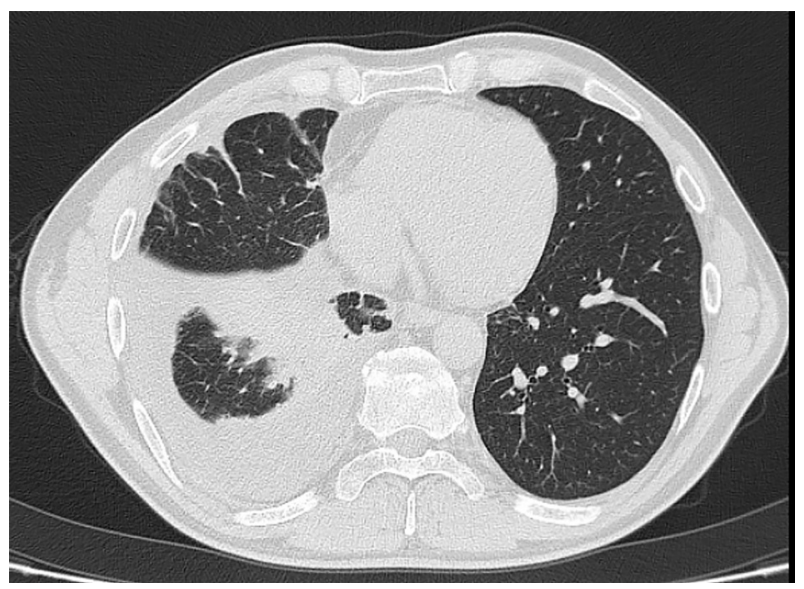

Figure 4. CT scans- October 2020: Right pleural effusion; bilateral pulmonary nodules, consolidation, bronchiectasis. and during the procedure of bronchoscopy, a bronchial aspirate was collected. We sent the samples for biochemical, microbiological and cytological tests. Besides the GeneXpert with a very low mycobacterial burden for Mycobacterium tuberculosis, all the tests came back negative.

During hospitalisation, the treatment consisted of antibiotics amoxicillin-clavulanic acid (1 g two times daily), a proton-pump inhibitor - omeprazole (20 mg daily) and anti-inflammatories ketoprofen (400 mg daily) and Medrol (8 mg daily). At discharge, the patient was asymptomatic.

At this point, we considered recommending a surgical biopsy. We postponed the procedure because we regarded tuberculosis as a possible diagnosis. The most important arguments were the patients' age, the history of lymphatic tuberculosis, and the single abnormal test being the GeneXpert for $M$. tuberculosis. We started the patient on antituberculous medication and scheduled a re-evaluation 2 months after discharge.

The patient returns to the emergency ward 2 weeks from discharge for severe right laterothoracic pain that subsequently extended to the left laterothoracic area and small hemoptysis. The chest $\mathrm{X}$-ray at presentation confirmed a right pleural effusion in aggravation and a new left pleural effusion smaller in size. To alleviate the pain and reduce breathing effort, we performed a therapeutic thoracocentesis and evacuated $1000 \mathrm{~mL}$ of hemorrhagic pleural fluid. Thus, we confirmed that the macroscopic characteristics of the pleural fluid had changed.

We repeated the chest $\mathrm{CT}$. The radiologist described stable lesions and lesions with a dimensional progression. The pulmonary consolidation situated in the left lower lobe and the diffuse pulmonary nodules had similar characteristics to the ones exhibited on the first examination. In contrast, the condensations in the right inferior and middle lobes were greater in size than on the first scan. Moreover, a new left pleural effusion became apparent (Figures 5-8).

In this context, surgical pleural biopsy remained the only option. The intraoperative histopathological exam was highly suggestive of neoplastic disease. For this reason, the surgeons performed pleurodesis using talc slurry. The macroscopic examination of the pleural lesions performed during surgery described them as white and adherent to the underlying tissue (Figures 9, 10).

The histopathological exam identified a series of possible diagnoses: biphasic mesothelioma, epitheliod haemangioendothelioma, metastatic sarcoma or carcinoma, and even a reactive process. Immunohistochemical tests were necessary for completing the differential diagnosis. The tumour tested positive for ERG, CD31, CD34, and AE1AE3; and negative for Calret. The definitive histopathological diagnosis was that of an EHE. 


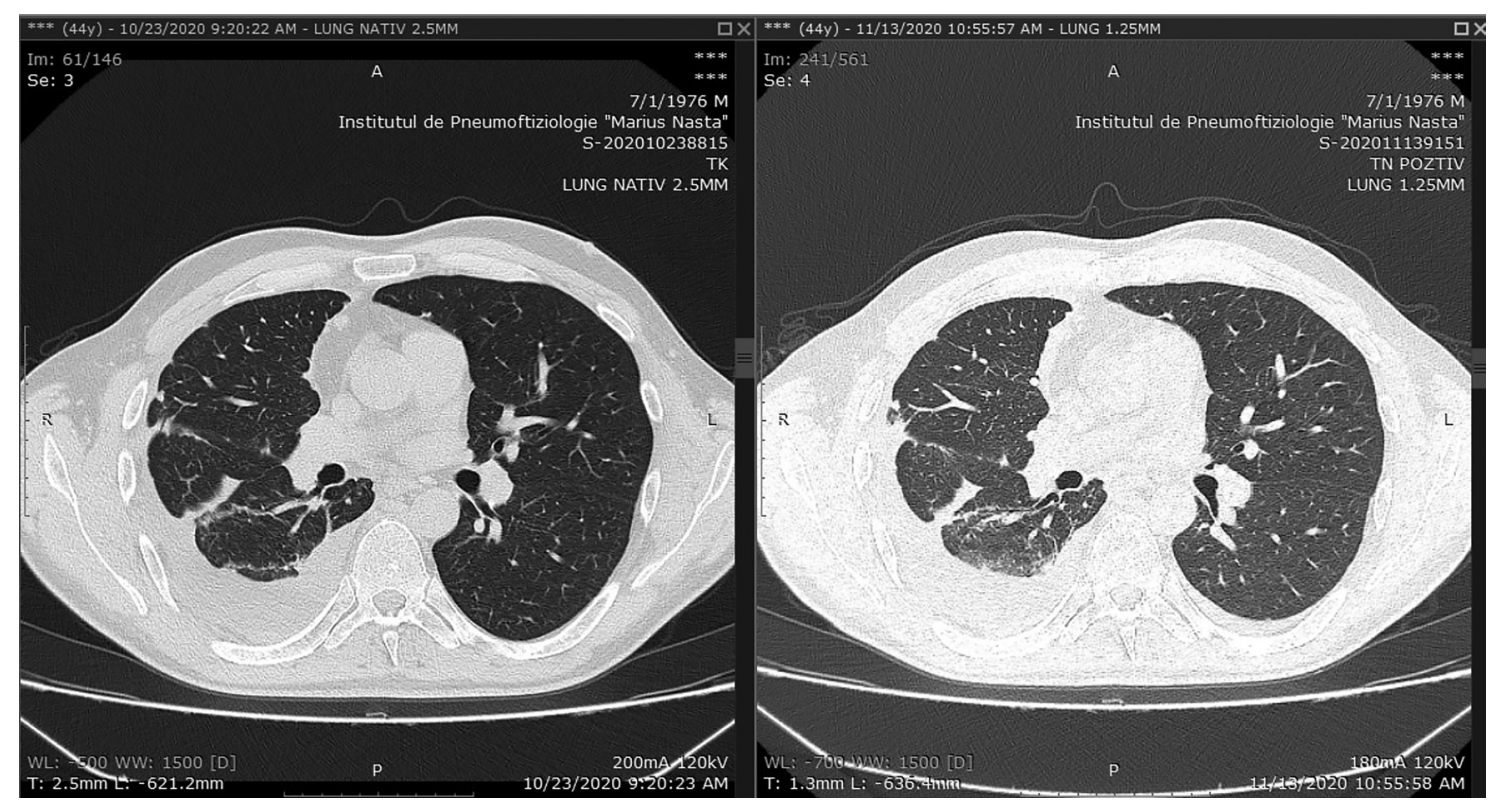

Figure 5. Comparative CT scans October- November 2020: Right pleural effusion, pulmonary consolidations and pulmonary nodules with similar characteristics.

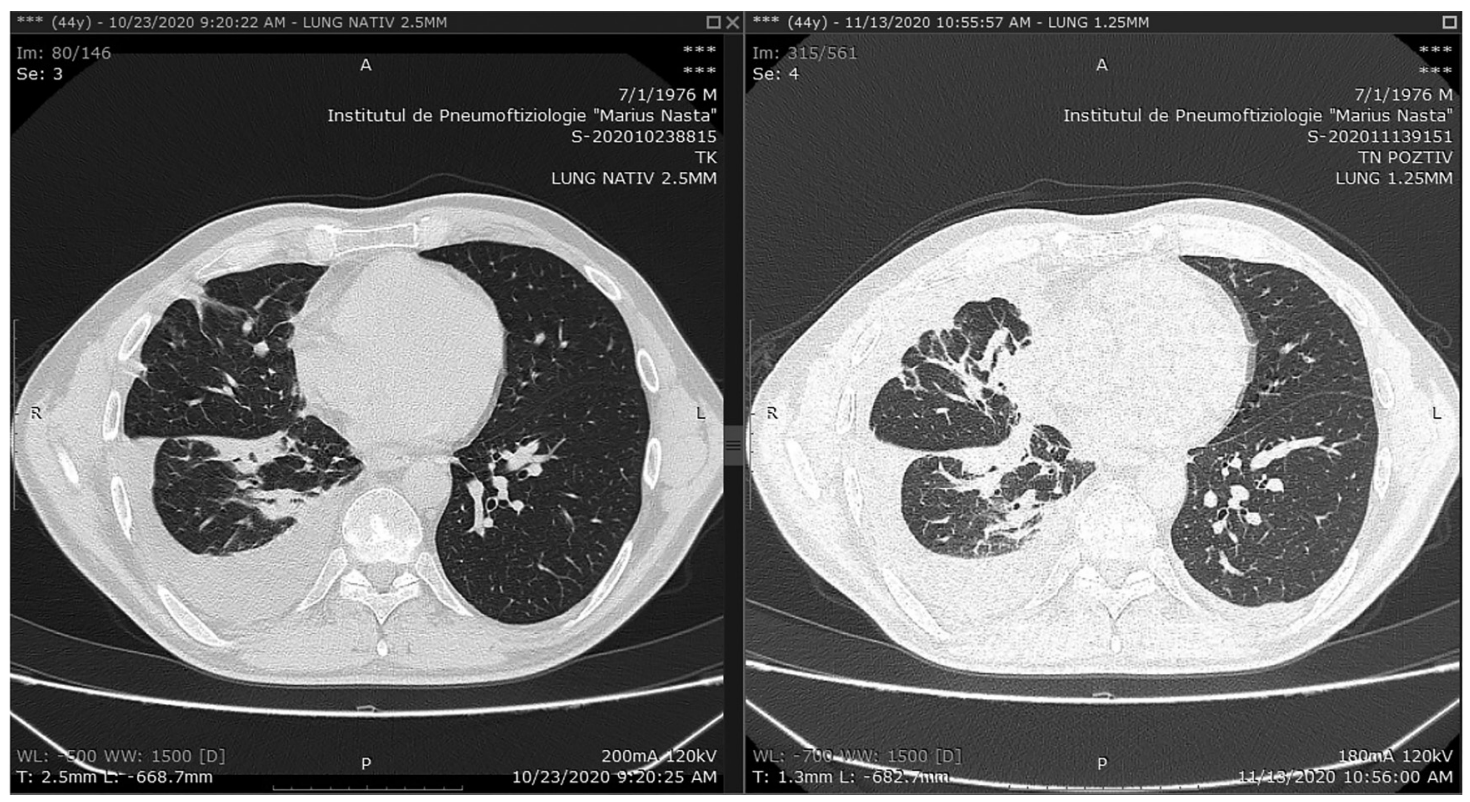

Figure 6. Comparative CT scans October- November 2020: Right pleural effusion, pulmonary consolidations situated in the middle lobe and in the left lower lobe in dimensional progression. New left pleural effusion.

Considering that the extension of the disease surgery was not among the treatment options, we referred the patient to an oncological ward for evaluation and targeted treatment. Furthermore, we advised the continuance of the antituberculous scheme.

\section{Discussion}

Confirming the neoplastic aetiology of a tumour implies a histopathological examination. When diagnosing EHE, surgical biopsies are usually necessary $(19,22)$. The 


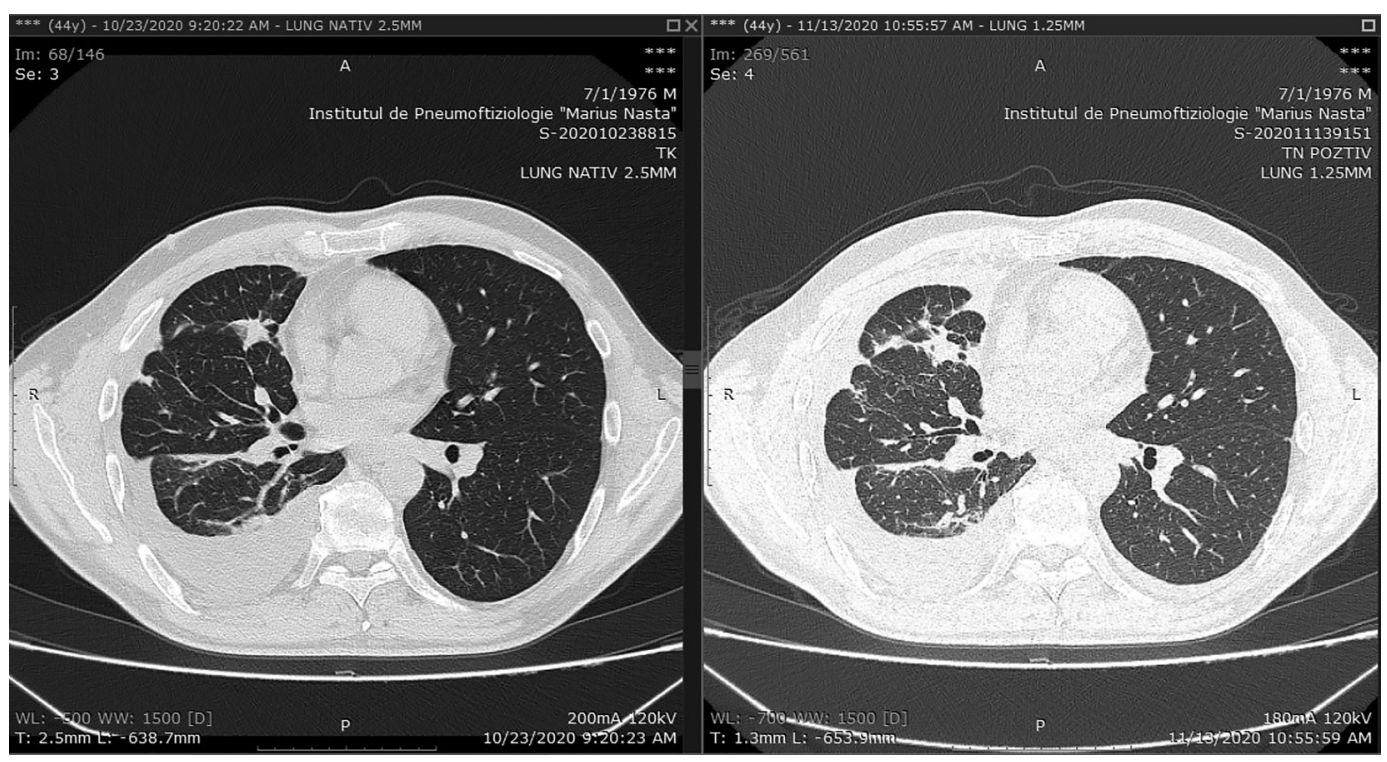

Figure 7. Comparative CT scans October- November 2020- Pulmonary window. Right pleural effusion, pulmonary consolidations situated in the middle lobe, left lower lobe, and right lower lobe in dimensional progression; new left pleural effusion.

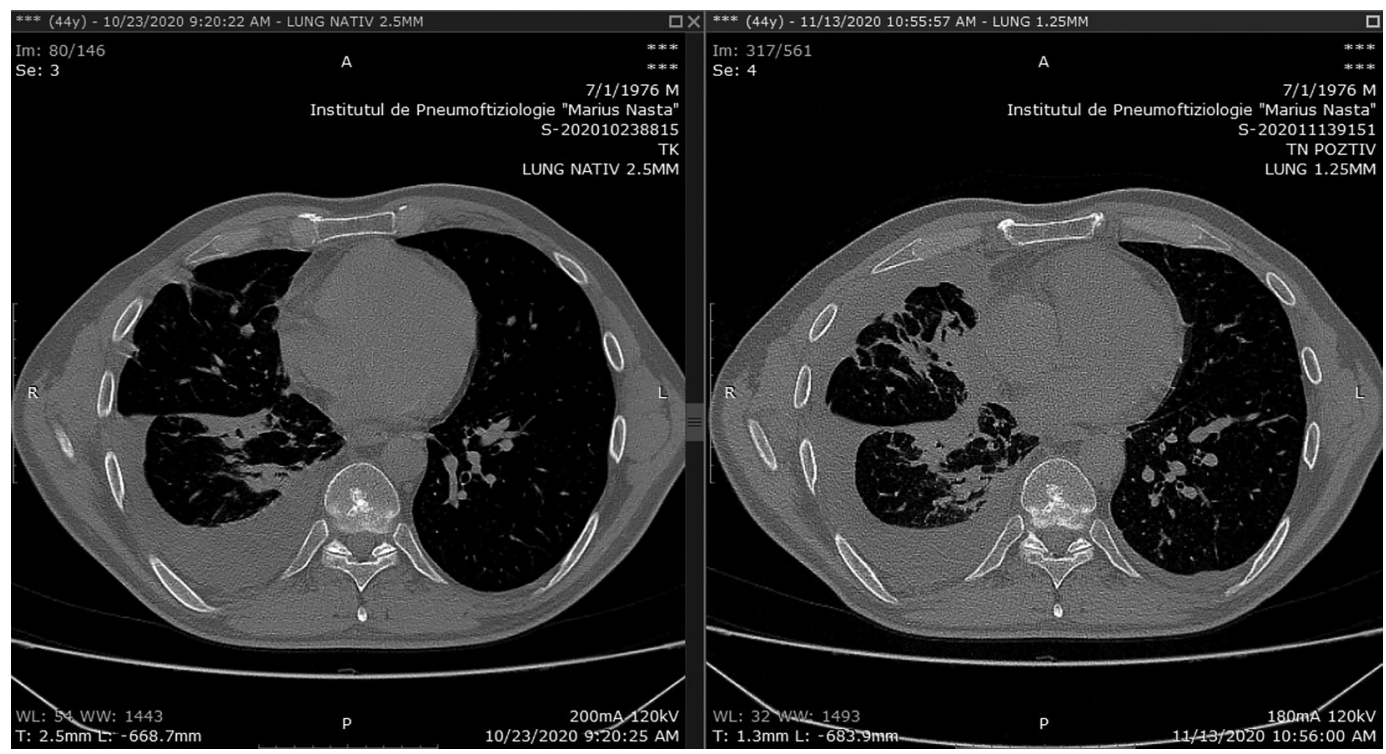

Figure 8. Comparative CT scans October- November 2020- Mediastinum window. Right pleural effusion, pulmonary consolidations situated in the middle lobe, left lower lobe, and right lower lobe in dimensional progression; new left pleural effusion.

intraoperative description of the lesions is compatible with data already published in this regard. The tumoural tissue seems to be white-gray, strongly adherent to the underlying structure, and presents an invasive potential (3). Moreover, immunohistochemistry is essential in the diagnosis of EHE. Friend leukemia integration 1 (Fli-1) transcription factor and CD34 are both markers whose presence certifies the vascular nature of the tumour (11). CD31 is more specific for EHE. It seems that a combination of CD31 and Fli-1 can provide both sensitivity and specificity in diagnosing EHE. $(4,20,21)$.

Molecular research proved that WWTR1-CAMATA1, a fusion protein, can be considered pathognomonic for EHE. This groundbreaking research facilitates the differential diagnosis. Epithelioid hemangioma and epithelioid angiosarcoma are entities that can be easily mistaken for $\operatorname{EHE}(20,21,23)$. 


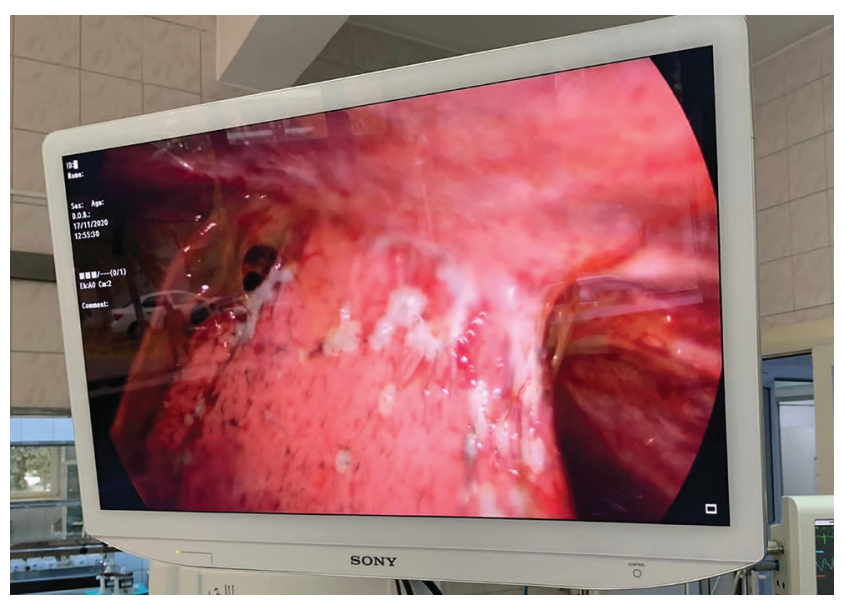

Figure 9. Intraoperative macroscopic examination: white adherent collections characteristic for both tuberculosis and neoplastic diseases.

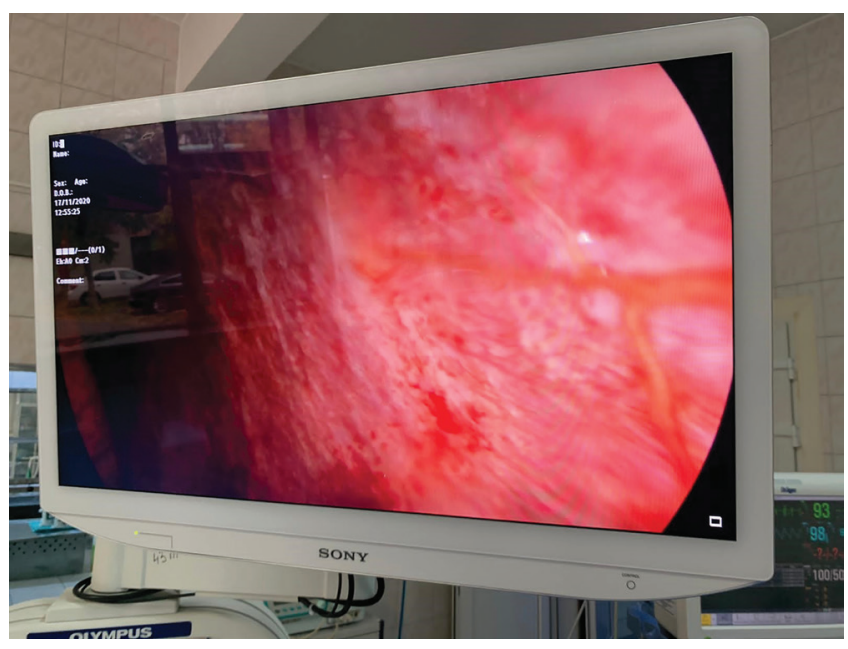

Figure 10. Intraoperative macroscopic examination: abnormal pleura.

In this patient, the tumour tested positive for AE1-AE3 antibody cocktail specific for epithelial cells and CD34 and ERG transcription factor, both suggestive for vascular tumours. It also tested positive for CD31, which presents a higher specificity for EHE. Molecular testing was not available.

EHE has been mistaken for tuberculosis in other reported cases. Xie XF et al. published a series of five cases. In two of the patients, they recommended a surgical biopsy after the failure of antituberculous treatment (19).

GeneXpert for M. tuberculosis can produce false-positive results for up to 4 years in patients that received complete treatment (24). The false-positive results are more common when the mycobacterial burden for $M$. tuberculosis is very low. Moreover, $95.8 \%$ have negative GeneXpert tests confirmed by negative cultures after 2 years from treatment completion (25). Our patient was diagnosed with tuberculosis $>20$ years ago, suggesting that suspicion of tuberculosis and commencement of treatment were justified.

We did not establish the aetiology of the pulmonary consolidations. The dimensional progression of the lesions, the fact that the lesions are invasive - obstructing bronchial structures - and the presence of a confirmed malignancy, are the arguments that plead towards a neoplastic disease. More explanations are possible. The lesions can represent a different malignancy, they can be a metastasis of the pleural malignancy, or the pleural malignancy could have appeared secondary to the pulmonary disease.

General symptoms such as weight loss, pulmonary symptoms such as hemoptysis, the presence of hemorrhagic pleural effusions, and an advanced disease with metastasis are prognostic factors for reduced survival rates $(3,26,27)$. Moreover, it seems that tumour size and increased mitotic activity influence survival rates (28). Our patient exhibits at least two elements linked with poor-survival rates - pulmonary symptoms and haemorrhagic pleural effusions.

The limited number of cases and the polymorphous nature of the disease treatment regimens impede the standardisation of treatment regimens. Sole monitorisation is an option in patients that exhibit a slow progression of the disease. Patients with limited lesions are candidates for curative surgical procedures, while patients with aggressive forms require conservative treatment. Invariably, invasive procedures are frequently necessary for diagnostic purposes - surgical biopsy. Studies regarding the use of chemotherapeutical agents, tyrosine-kinase inhibitors and even immunomodulators are available.

Combinations such as carboplatin-etoposide (29), carboplatinpaclitaxel- bevacizumab (30) and even monotherapy using alpha-interferon $(16,30,31)$ or azathioprine proved to be useful in treating patients with EHE. Another therapeutic strategy involves targeting the overexpression of vascular endothelial growth factor. Tyrosine-kinase inhibitors such as apatinib (23), sorafenib (32) and pazopanib (33) triggered at least partial responses.

Stacchiotti et al. proved that Sirolimus in a $4.5 \mathrm{mg}$ daily dose was effective in $81 \%$ of the patients with EHE that entered the study. The success was indicated either by a stabilisation of the disease or by a partial response (34).

Treatment success rates were not stratified according to the characteristics of the patients. That is why it is difficult to establish which type of agent would bring more benefits to which patient. In conclusion, when treating a patient with pleural effusion, the lack of improvement despite administering treatment entails reconsidering the initial diagnosis and performing more extensive tests. EHE, although very rare, must be kept in mind as a possible cause of pleural effusions. Further research is necessary for establishing standardised treatment regimens. 


\section{Conflict of interest}

The authors have no conflict of interest.

\section{Ethical approval}

Patient informed consent was obtained.

\section{References}

1. Clive AO, Bhatnagar R, Preston NJ, Jones HE, Maskell N. Interventions for the management of malignant pleural effusions: A network meta-analysis. Cochrane Database Syst Rev. 2016(5):CD010529. doi: 10.1002/14651858.CD010529.pub2.

2. Murray JF, Nadel JA. Textbook of Respiratory Medicine. ed. Elsevier Saunders; 2016;1: 1396-1487.

3. McAdams HP, Crotty EJ, Erasmus JJ, Sporn TA, Roggli VL. Epithelioid hemangioendothelioma of the pleura clinical and radiologic features. Am Journ Roentgenol. 2000;175(6): 1545-1549.

4. Cohen PJ, Chawla M, Bansal A, Kwon JS. Pleural epithelioid hemangioendothelioma. Lung. 2012;190(4): 469-470.

5. Reade CA, Ganti AK, Kessinger A. Clinicopathologic characteristics of primary pleural epithelioid hemangioendothelioma. Oncol Rev. 2010;4(4): 219-222.

6. Rosenberg A, Agulnik M. Epithelioid hemangioendothelioma: Update on diagnosis and treatment. Curr Treat Options Oncol. 2018;19(4): 1-8.

7. Ellis GL, Kratochvil III FJ. Epithelioid hemangioendothelioma of the head and neck: A clinicopathologic report of twelve cases. Oral Surg Oral Med Oral Pathol. 1986;6(1): 61-68.

8. Hahn E, Dickson BC, Gupta AA, Nofech-Mozes S. Case of epithelioid hemangioendothelioma occurring in the postradiation setting for breast cancer. Genes Chrom Cancer. 2021;60(2): 112-115.

9. Silva EG, Philips MJ, Ordonez NG, Langer B. Spindle and histiocytoid (epithelioid) hemangioendothelioma: Primary in lymph node. Am J Clin Pathol. 1986;85(6): 731-735.

10. Napaki S, Stirling JW. Spindle and epithelioid (histiocytoid) hemangioendothelioma of cervical lymph nodes. Pathology. 2004;36(6): 587-589.

11. Tammam AG, Lewis PD, Crockard HA. Cerebellopontine angle epithelioid hemangioendothelioma in a 4-year-old boy. Child's Nervous System. 1997;13(11-12): 648-650.

12. Iueca C, Machado I, Almenar S, Garcia A, Covisa A, Morales J, et al. Uncommon vascular tumor of the ovary. Primary ovarian epithelioid hemangioendothelioma or vascular sarcomatous transformation in ovarian germ cell tumor? Arch Gynecol Obstet. 2011;284(6): 1589-1591.
13. Iyer A, Thompson L, Cooper K. Epithelioid hemangioendothelioma, mimicking prostatic adenocarcinoma. Histopathology. 2011;60: 511-527

14. 15. Al-Faky YH, Al Malki S, Raddaoui E. Hemangioendothelioma of the eyelid can mimic chalazion. Oman J Ophthalmol. 2011;4(3): 142-143.

15. Kitaichi M, Nagai $\mathrm{S}$, Nishimura $\mathrm{K}$, Itoh $\mathrm{H}$, Asamoto $\mathrm{H}$, Izumi $\mathrm{T}$, et al. Pulmonary epithelioid haemangioendothelioma in 21 patients, including three with partial spontaneous regression. Eur Respir J. 1998;12(1): 89-96.

16. Bagan P, Hassan M, Barthes FL, Peyrard S, Souilamas R, Danel $C$, et al. Prognostic factors and surgical indications of pulmonary epithelioid hemangioendothelioma: A review of the literature. Ann Thorac Surg. 2006;82(6): 2010-2011.

17. Erasmus JJ, McAdams HP, Carraway MS. A 63-year-old woman with weight loss and multiple lung nodules. Chest. 1997;111(1): 236-238.

18. Wu X, Li B, Zheng C, Hong T, He X. Clinical characteristics of epithelioid hemangioendothelioma: A single-center retrospective study. Eur J Med Res. 2019;24(1): 16.

19. Mesquita RD, Sousa M, Trinidad C, Pinto E, Badiola IA. New insights about pulmonary epithelioid hemangioendothelioma: Review of the literature and two case reports. Case Rep Radiol. 2017;14.

20. Xie XF, Huang Y, Guo JH, Zhang W, Hou LK, Wu CY, et al. Often misdiagnosed primary pleural epithelioid hemangioendothelioma: A clinicopathological analysis of five cases. Chin J Pathol. 2020;49(12): 1288-1293.

21. Sardaro A, Bardoscia L, Petruzzelli MF, Portaluri M. Epithelioid hemangioendothelioma: An overview and update on a rare vascular tumor. Oncol Rev. 2014;8(2): 259.

22. Murali R, Zarka MA, Ocal IT, Tazelaar HD. Cytologic features of epithelioid hemangioendothelioma. Am J Clin Pathol. 2011;136(5): 739-746.

23. Doyle LA. Sarcoma classification: An update based on the 2013 World Health Organization classification. Curr Treat Options Oncol. 2014;120(12): 1763-1774.

24. Kobayashi N, Shimamura T, Tokuhisa M, Goto A, Ichikawa Y. Sorafenib monotherapy in a patient with unresectable hepatic epithelioid hemangioendothelioma. Case Rep Oncol. 2016;9(1): 134-137.

25. Costantini L, Marando M, Gianella P. Long-term GeneXpert positivity after treatment for pulmonary tubercolosis. Eur J Case Rep Intern Med. 2020;7(10): 1737.

26. Theron G, Venter R, Smith L, Esmail A, Randall P, Sood V, et al. False-positive Xpert MTB/RIF results in retested patients with previous tuberculosis: Frequency, profile, and prospective clinical outcomes. J Clin Microbiol. 2018;56(3): e01696.

27. Barthes FL, Hassan M, Bagdan P, Peyrard S, Souilamas R, Danel $\mathrm{C}$, et al. Prognostic factors and surgical indications of pulmonary epithelioid hemangioendothelioma: A review of the literature. Ann Thor Surg. 2006;82(6): 2010-2013. 
28. Rosengarten D, Kramer MR, Amir G, Fuks L, Berkman N. Pulmonary epithelioid hemangioendothelioma. Israel Med Assoc J. 2011;13(11): 676-679.

29. Deyrup AT, Tighiouart M, Montag AG, Weiss SW. Epithelioid hemangioendothelioma of soft tissue: A proposal for risk stratification based on 49 cases. Am J Surg Pathol. 2008;32(6): 924-927.

30. Pinet C, Magnan A, Garbe L, Payan MJ, Vervolet D. Aggressive form of pleural epithelioid haemangioendothelioma: Complete response after chemotherapy. Eur Respir J. 1999;14(1): 237-238.

31. Gaur S, Torabi A, O'Neill TJ. Activity of angiogenesis inhibitors in metastatic epithelioid hemangioendothelioma: A case report. Cancer Biol Med. 2012;9(2): 133-136.
32. Roudier-Pujol C, Enjolras O, Lacronique J, Guillemette J, Herbreteau D, Leibowitch M, et al. Multifocal epithelioid hemangioendothelioma with partial remission after interferon alfa-2a treatment. Ann Dermatol Venereol. 1994;121(12): 898-904.

33. Stacchiotti S, Provenzano S, Dagrada G, Negri T, Brich S, Basso $U$, et al. Sirolimus in advanced epithelioid hemangioendothelioma: A retrospective case-series analysis from the Italian rare cancer network database. Ann Surg Oncol. 2016;23(9): 2735-2744. doi: 10.1245/s10434-016-5331-z.

34. Semenisty V, Naroditsky I, Keidar Z, Bar-Sela G. Pazopanib for metastatic pulmonary epithelioid hemangioendothelioma-a suitable treatment option: Case report and review of antiangiogenic treatment options. BMC Cancer. 2015;15(1): 402. doi: 10.1186/s12885-015-1395-6. 